\title{
Pengaruh Kontrol Diri Terhadap Prokrastinasi Akademik Siswa Kelas XI SMA N 1 Kedungwuni
}

\author{
Dea Farah Aisy \\ Universitas Negeri Semarang, Semarang, Indonesia \\ deafarahaisy@gmail.com \\ Sugiyo \\ Universitas Negeri Semarang, Semarang, Indonesia \\ sgy11@mail.unnes.ac.id
}

\begin{abstract}
Abstrak
Penelitian ini bertujuan untuk mendeskripsikan data mengenai tingkat kontrol diri, tingkat prokrastinasi akademik serta mengetahui seberapa besar pengaruh kontrol diri terhadap prokrastinasi akademik. Penelitian ini menggunakan desain kuantitatif korelasional. Sampel yang digunakan berjumlah 161 dari 309 peserta didik dengan teknik pengambilan sampel cluster sampling. Alat pengumpulan data yang digunakan adalah skala prokrastinasi akademik, skala kontrol diri, dan wawancara. Adapun teknik analisis data menggunakan analisis deskriptif kuantitatif dan analisis statistik inferensial dengan teknik regresi sederhana. Hasil analisis deskriptif menunjukkan bahwa rata-rata tingkat prokrastinasi akademik sebesar 2,62 yang berada pada kategori cukup. Sedangkan rata-rata tingkat kontrol diri sebesar 3,47 yang masuk dalam kategori tinggi. Sedangkan analisis statistik inferensial menunjukkan terdapat pengaruh yang signifikan antara kontrol diri terhadap prokrastinasi akademik ( $R$ square $=0,584$ ) artinya terdapat pengaruh sebesar 58,4\% kontrol diri terhadap prokrastinasi akademik
\end{abstract}

Kata kunci: Kontrol Diri, Prokrastinasi Akademik, Peserta Didik

\section{Abstract}

The Effect of Self-Control on Academic Procrastination of Class XI Students of SMA N 1 Kedungwuni. This study aims to describe the data regarding the level of self-control, the level of academic procrastination and 
find out how much influence self-control on academic procrastination. This study uses a correlational quantitative design. The samples used were 161 of 309 students with cluster sampling techniques. Data collection tools used were academic procrastination scales, self-control scales, and interviews. The data analysis technique uses quantitative descriptive analysis and inferential statistical analysis with simple regression techniques. Descriptive analysis results show that the average level of academic procrastination of 2.62 is in the sufficient category. While the average level of self-control of 3.47 is included in the high category. While inferential statistical analysis shows that there is a significant influence between self control on academic procrastination $(R$ square $=0.584$ ) meaning that there is an influence of $58.4 \%$ self control on academic procrastination.

Keywords: Self Control, Academic Procrastination, Students

\section{A. Pendahuluan}

Layanan bimbingan dan konseling bidang belajar bertujuan untuk membantu individu dalam mengatasi masalah-masalah dalam belajar. Sedangkan layanan bimbingan dan konseling bidang pribadi bertujuan untuk membantu peserta didik memahami, menilai, dan mengembangkan potensi dan kecakapan, bakat dan minat, sesuai karakteristik dan kebutuhan dirinya. Maka dapat dilihat secara umum bahwa tujuan bimbingan dan konseling selaras dengan pendidikan sendiri yaitu sebagai wadah pengembangan.

Namun faktanya pada era globalisasi ini, remaja cenderung krisis dimana lunturnya sikap peduli terhadap orang lain, lunturnya cinta terhadap budaya sendiri, serta lebih mementingkan diri sendiri tanpa melihat nilai-nilai yang ada di lingkungan mereka. Sehubungan dengan tujuan pendidikan, salah satu tugas perkembangan remaja yaitu mengembangkan perilaku tanggung jawab sosial yang diperlukan untuk memasuki dunia dewasa.

Permasalahan dalam pendidikan yang banyak dialami sebagian besar pelajar yaitu prokrastinasi akademik. Menurut Solomon dan Rothblum, prokrastinasi akademik merupakan menunda untuk mengerjakan atau menyelesaikan tugas yang dilakukan secara sengaja. Terkait hal tersebut 
manajemen diri yang optimal khususnya kontrol diri merupakan tuntutan penting bagi remaja dalam proses pembelajaran untuk menghindari prokrastinasi akademik sehingga remaja tidak mengalami krisis identitas dan dapat berkembang sesuai dengan norma yang berlaku di lingkungannya (Nova 2012). Kontrol diri sendiri merupakan kemampuan seseorang membimbing, mengatur, dan mengarahkan bentuk-bentuk perilaku melalui pertimbangan kognitif yang dapat membawa ke arah positif (Hurlock 1994).

Hasil wawancara yang dilakukan peneliti dengan guru BK kelas XI SMA N 1 Kedungwuni pada hari Senin tanggal 21 Januari 2019 menjelaskan bahwa adanya beberapa peserta didik yang melakukan prokrastinasi. Ketika jam kosong dan diberikan tugas, beberapa peserta didik memilih untuk tidak mengerjakannya secara langsung. Beberapa hal yang dilakukan peserta didik seperti bermain gadget, bercanda dengan temannya, pergi ke kantin, serta mengerjakan tugas lain. Guru BK menjelaskan bahwa masih banyaknya peserta didik yang mengeluh ketika diberikan tugas. Sedangkan menurut Ferrari dkk ciri-ciri perilaku prokrastinasi akademik yaitu menunda untuk memulai dan menyelesaikan tugas, terlambat mengerjakan tugas, kesenjangan waktu antara rencana dan kinerja aktual, dan melakukan aktivitas yang lebih menyenangkan (Ghufron, N. M. \& Risnawati 2016). Dari ciri-ciri tersebut terlihat bahwa peserta didik melakukan perilaku prokrastinasi akademik. Dalam penelitian ini dilakukan pula pengambilan data awal menggunakan skala likert untuk mengetahui seberapa banyak prosentase peserta didik yang melakukan prokrastinasi akademik. Diketahui bahwa sebanyak 60\% peserta didik kelas XI SMA N 1 Kedungwuni tergolong dalam kategori tinggi dan 33\% masuk dalam kategori sedang.

Penelitian ini diarahkan secara khusus untuk membuktikan pengaruh kontrol diri terhadap prokrastinasi akademik. Penelitian ini menjadi penting karena hasil dari penelitian ini diharapkan dapat dimanfaatkan oleh guru BK sebagai bahan masukan dalam mengurangi prokrastinasi akademik peserta didik 
melalui peningkatan kontrol diri yang diberikan melalui layanan bimbingan dan konseling.

Tujuan bimbingan dan konseling adalah untuk mengembangkan potensi pada individu seoptimal mungkin, sesuai dengan kemampuan agar bisa menyesuaikan diri dengan lingkungannya, baik lingkungan sekolah, keluarga maupun lingkungan masyarakat (Bastomi, 2020). Menurut Yusuf \& Nurihsan dalam Bastomi (2019) Proses Bimbingan dan Konseling di sekolah dapat berhasil apabila mempunyai tujuan yang jelas yang akan dicapainya. Bimbingan dan konseling bertujuan untuk membantu peserta didik agar dapat mencapai tujuantujuan perkembangannya yang meliputi aspek pribadi-sosial belajar (akademik) dan karir. Sedangkan tujuan bimbingan dan konseling Islam menurut Mubarok dalam Bastomi (2017) Secara singkat dapat dirumuskan sebagai berikut : (1) Tujuan umum Konseling Islam untuk membantu konseli agar dia memiliki pengetahuan tentang posisi dirinya dan memiliki keberanian mengambil keputusan, untuk melakukan suatu perbuatan yang dipandang baik, benar dan bermanfaat, untuk kehidupannya di dunia dan untuk kepentingan akhiratnya. (2) Tujuan khusus bimbingan konseling Islam adalah: (a) Untuk membantu konseli agar tidak menghadapi masalah. (b) Untuk membantu konseli mengatasi masalah yang sedang dihadapinya. (c) Untuk membantu konseli memelihara dan mengembangkan situasi dan kondisi yang baik atau yang telah baik agar tetap baik, sehingga tidak akan menjadi sumber masalah bagi dirinya dan orang lain. Guna mencapai tujuan bimbingan konseling sesuai yang diharapkan tentunya proses manajemen bimbingan dan konseling harus berjalan dengan sangat baik.

\section{B. Metode}

1. Metode Penelitian

Penelitian ini menggunakan desain penelitian kuantitatif korelasional. Penelitian kuantitatif merupakan jenis penelitian yang menghasilkan temuan baru yang dapat diperoleh dengan menggunakan prosedur-prosedur secara statistik 
atau cara lainnya dari suatu kuantifikasi (pengukuran) (Mertha Jaya 2020). Penelitian ini bertujuan untuk mencari pengaruh kontrol diri terhadap prokratinasi akademik peserta didik. Hubungan-hubungan antar variabel tersebut kemudian dianalisis dengan menggunakan teori yang objektif.

Menurut Arikunto metode pengumpulan data merupakan cara-cara yang dapat digunakan peneliti untuk mengumpulkan data (Arikunto 2007). Dalam penelitian, pengumpulan data merupakan hal terpenting untuk mendapatkan data. Data yang dikumpulkan peneliti adalah data-data terkait variabel penelitian. Pada penelitian ini data yang akan dikumpulkan yaitu terkait kontrol diri dan prokrastinasi akademik peserta didik kelas XI SMA N 1 Kedungwuni. Metode pengumpulan data yang digunakan dalam penelitian ini yaitu skala psikolo gis. Menurut Azwar skala psikologis merupakan alat ukur yang memiliki karakteristik khusus dan cenderung digunakan untuk mengukur aspek afektif bukan kognitif (A. 2014). Skala psikologis ini sebagai alat untuk mengungkapkan konstrak atau konsep psikologis yang menggambarkan aspek kepribadian. Pada penelitian ini menggunakan instrument skala likert. Menurut Sugiyono skala likert ini digunakan untuk mengukur sikap, pendapat, dan persepsi seseorang atau kelompok tentang fenomena social (Sugiyono 2016).

2. Populasi dan Sampel

Penelitian ini menggunakan populasi peserta didik kelas XI SMA N 1 Kedungwuni. Karakteristik populasi dalam penelitian ini yaitu peserta didik dalam satu sekolah yang sama dan berusia antara 17-18 tahun (remaja) sebanyak 309 peserta didik. Sedangkan sampel yang digunakan sebanyak 161 peserta didik dengan menggunakan teknik cluster sampling.

\section{Instrumen}

Pada penelitian ini menggunakan alat pengumpul data berupa skala prokrastinasi akademik dan skala kontrol diri. Pada skala prokrastinasi akademik berisi tentang pernyataan-pernyataan untuk mengungkap indikator-indikator 
prokrastinasi akademik. Skala prokrastinasi akademik ini disusun sesuai kisi-kisi skala prokrastinasi akademik. Pada skala kontrol diri berisi tentang pernyataan pernyataan untuk mengungkap indikator-indikator kontrol diri. Skala kontrol diri ini disusun sesuai kisi-kisi skala kontrol diri. Instrumen tersebut disusun sesuai dengan pola skala likert, pernyataan dalam skala prokrastinasi akademik disajikan dikemas dalam dua arah yaitu positif $(+)$ dan negatif (-).Dalam skala likert yang telah dimodifikasi, ada lima tingkat jawaban terkait kesesuaian responden, yaitu Sangat Sesuai (SS), Sesuai (S), Kurang Sesuai (KS), Tidak Sesuai (TS), Sangat Tidak Sesuai (STS).

4. Validitas dan realibilitas instrument

Berdasarkan uji validitas skala prokrastinasi akademik, diperoleh 35 item yang valid dari 40 item, jadi terdapat 5 item yang tidak valid. Pada pengujian validitas terdapat 34 responden, sehingga pada analisis product moment dengan taraf signifikansi $5 \%$ diketahui $r_{\text {tabel }}=0,339$. Sedangkan uji validitas skala kontrol diri, diperoleh 28 item yang valid dari 36 item, jadi terdapat 7 item yang tidak valid. Pada pengujian validitas terdapat 34 responden, sehingga pada analisis product moment dengan taraf signifikansi 5\% diketahui $\mathrm{r}_{\text {tabel }}=0,339$.

Berdasarkan hasil uji reliabilitas terhadap 34 peserta didik yang menggunakan program SPSS dan rumus Alpha Cronbach's dengan taraf kesalahan $5 \%$ diperoleh koefisien skala prokrastinasi akademik 0,921 dan skala kontrol diri 0,883 sehingga skala prokrastinasi akademik dan skala kontrol diri dinyatakan reliable untuk digunakan sebagai alat ukur. Hal ini dikarenakan skala prokrastinasi akademik dan skala kontrol diri tersebut termasuk dalam kriteria tinggi sesuai dengan tabel kriteria reliabilitas.

Tabel 1. Klasifikasi Koefisien Reliabilitas

\begin{tabular}{|l|l|}
\hline Koefisien reliabilitas & Keterangan klasifikasi \\
\hline $0,80 \leq \mathrm{r}<1,00$ & Reliabilitas sangat tinggi \\
\hline $0,60 \leq \mathrm{r}<0,80$ & Reliabilitas tinggi \\
\hline $0,40 \leq \mathrm{r}<0,60$ & Reliabilitas cukup \\
\hline $0,20 \leq \mathrm{r}<0,40$ & Reliabilitas rendah \\
\hline $0,00 \leq \mathrm{r}<0,20$ & Reliabilitas sangat rendah \\
\hline
\end{tabular}




\section{Analisis data}

Penelitian kuantitatif ini merupakan kegiatan setelah data dari seluruh responden terkumpul. Setelah seluruh data terkumpul dilakukan teknik analisis data untuk memperoleh hasil penelitian. Untuk mengetahui pengaruh kontrol diri terhadap prokrastinasi akademik, maka penelitian ini menggunakan analisis data (1) analisis deskriptif, (2) uji persyaratan analisis, dan (3) uji hipotesis dengan regresi sederhana.

\section{Pembahasan}

\section{Prokrastinasi Akademik}

Prokrastinasi dalam bahasa latin yaitu prokratination yang berawal dari kata "pro" yang berarti mendorong maju dan memiliki akhiran "crastinus" yang berarti keputusan hari esok. Jadi dapat diketahui bahwa prokrastinasi memiliki arti menangguhkan atau menunda sampai akhir berikutnya (Burka, J.B \& Yuen 2008).

Menurut Solomon dan Rothblum prokrastinasi merupakan penundaan dalam pengerjaan dan penyelesaian tugas yang dilakukan secara sengaja. Prokrastinasi akademik mengacu pada keterlambatan tingkah laku dan tekanan psikologis yang terjadi ketika individu harus memertimbangkan hubungan antara penunadaan dengan konsekuensi psikologis yang dialaminya. Konsekuensi psikologis ini berupa ketidaknyamanan emosional, rasa bersalah, depresi, stres, dan kecemasan.

Menurut Millgram prokrastinasi memiliki perilaku yang spesifik, yaitu (1) perilaku menunda tugas baik dalam memulai maupun menyelesaikan; (2) berakibat negatif dalam penyelesaian tugas; (3) persepsi procrastinator pada tugas; (4) keadaan emosional prokrastinator yang tidak menyenangkan misalnya cemas, khawatir,dan takut (Ghufron, N. M. \& Risnawati 2016). Prokrastinasi 
akademik dianggap sebagai penundaan yang tidak berguna. Penundaan ini berakibat pada pengerjaan tugas atau pekerjaan yang dilakukan menjadi tidak maksimal dan tugas hanya dikerjakan sebagai syarat pemenuhan tugas saja.

Dari pendapat diatas dapat disimpulkan bahwa prokrastinasi akademik merupakan perilaku menunda tugas akademik yang dilakukan oleh seorang peserta didik atau prokrastinator baik disengaja maupun tidak sengaja yang disebabkan oleh faktor internal dan eksternal, sehingga memiliki dampak buruk bagi diri sendiri, seperti timbul rasa cemas dan panik, serta banyak menyita waktu dalam menyelesaikan tugas yang juga berakibat pada kemunduran dalam menyelesaikan tugas-tugas lainnya.

Solomon dan Rothblum mengemukakan bahwa prokrastinasi akademik biasa terjadi pada enam area akademik, yaitu sebagai berikut (Solomon 1984).

a. Tugas mengarang

Tugas yang meliputi penundaan dalam pengerjaan tugas menulis, misalnya menulis makalah, laporan, dan pekerjaan rumah (PR).

b. Tugas belajar menjelang ujian

Tugas yang meliputi penundaan dalam belajar untuk menghadapi ujian, misalnya ujian tengah semester, ujian akhir seester, dan ulangan mingguan.

c. Tugas membaca mingguan

Tugas yang meliputi penundaan dalam membaca buku atau referensi terkait tugas akademik.

d. Tugas administratif

Tugas yang meliputi penundaan dalam menyalin catatan, pendaftaran presensi kehadiran, serta daftar peserta praktikum.

e. Tugas Kehadiran

Tugas yang meliputi penundaan dalam menghadiri kegiatan, misalnya terlambat masuk kelas, terlambat konsultasi dengan guru, serta terlambat menghadiri seminar.

f. Kinerja akademik secara keseluruhan 
Tugas yang meliputi penundaan secara keseluruhan dalam kinerja akademik atau pengerjaan tugas secara menyeluruh.

Berdasarkan penjelasan di atas, dapat disimpulkan bahwa prokrastinasi akademik terjadi dalam enam area, yaitu tugas mengarang, tugas belajar menjelang ujian, tugas membaca mingguan, tugas administratif, tugas kehadiran, dan kinerja akademik secara keseluruhan.

\section{Kontrol Diri}

Goldfried dan Merbaum mengartikan kontrol diri merupakan suatu kemampuan untuk menyusun, membimbing, mengatur, dan mengarahkan bentuk perilaku yang dapat membawa individu ke arah konsekuensi positif (Muhid 2009). Menurut Hurlock kontrol diri merupakan kemampuan seseorang membimbing, mengatur, dan mengarahkan bentuk-bentuk perilaku melalui pertimbangan kognitif yang dapat membawa ke arah positif (Hurlock 1994). Oleh karena itu, kemampuan seseorang dalam mengontrol dirinya sangat berkaitan dengan bagaimana seseorang tersebut mengendalikan emosi serta dorongan yang ada di dalam dirinya.

Sedangkan menurut Ghufron kontrol diri merupakan suatu kecakapam individu dalam kepekaan membaca situasi diri, lingkungan, serta kemampuan untuk mengontrol dan mengelola perilaku sesuai kondisi yang bertujuan untuk menampilkan diri dalam bersosialisasi, menarik perhatian, dan menyenangkan orang lain (Ghufron, N.M. \& Risnawati 2010). Sementara itu, Harter berpendapat bahwa dalam diri seseorang terdapat serangkaian system yang berkaitan berupa pengaturan diri (self-regulation) yang memusatkan perhatian ke pengontrolan diri (self-control) (Santrock 2003). Di dalam proses pengaturan diri ini menjelaskan bagaimana diri seseorang mengatur serta mengendalikan perilaku dalam menjalani kehidupan sesuai dengan kemampuan individu tersebut. Apabila individu tersebut dapat mengendalikan perilakunya dengan baik maka individu 
tersebut dapat menjalani kehidupan dengan baik. Sebaliknya, apabila individu tersebut tidak dapat mengendalikan perilakunya dengan baik maka individu tersebut tidak dapat menjalani kehidupannya dengan baik.

Dari beberapa pernyataan para ahli yang telah diuraikan, maka dapat disimpulkan bahwa kontrol diri adalah kemampuan individu untuk mengatur, mengendalikan, mengarahkan, serta mengubah perilakunya kearah yang lebih positif.

Menurut Averill kontrol diri terdiri dari tiga aspek, berikut aspek-aspek dari kontrol diri (Ghufron 2003).

a. Kontrol Perilaku

Kontrol perilaku merupakan kemmapuan individu untuk merespon suatu kejadian yang tidak diinginkan. Kontrol perilaku sendiri memiliki komponen untuk mengatur pelaksanaan dan memodifikasi stimulus terhadap kejadian yang tidak dikehendaki.

b. Kontrol Kognitif

Kontrol kognitif merupakan kemampuan individu mengolah informasi yang tidak diinginkan dengan menilai suatu kejadian dalam kerangka kognitif untuk mengurangi tekanan. Kontrol kognitif sendiri terdiri dari dua komponen yaitu untuk mengolah informasi dan melakukan penilaian.

c. Mengontrol Keputusan

Mengontrol keputusan merupakan kemampuan memilih hasil atau suatu tindakan berdasarkan pada keyakinan. Dalam hal ini kontrol diri akan berfungsi dengan adanya kesempatan, kebebasan, serta kemungkinan pada individu untuk memilih tindakan yang akan dilakukan.

\section{Tingkat Kontrol Diri Peserta didik kelas XI SMA N 1 Kedungwuni}

Tingkat kontrol diri peserta didik kelas XI SMA N 1 Kedungwuni secara umum termasuk dalam kategori yang tinggi $(M=3,47$ dan $S D=0,42)$, yang artinya 
peserta didik memiliki kemampuan dalam mengontrol dirinya sendiri seperti mengontrol diri dalam berperilaku, mengontrol diri menggunakan kognitifnya, dan mengontrol diri dalam pengambilan keputusan. Berdasarkan hasil perhitungan tingkat kontrol diri peserta didik, diketahui bahwa indikator dengan rata-rata tertinggi adalah kemampuan peserta didik dalam mengontrol keputusan $(M=3,64$ dan $\mathrm{SD}=0,45$ ). Hal ini menggambarkan bahwa peserta didik mampu mengambil keputusan untuk dirinya. Sedangkan indikator rata-rata terendah adalah kontrol kognitif $(M=3,33$ dan $S D=0,431)$. Hal ini menggambarkan bahwa peserta didik belum mampu mengontrol kognitif dirinya.

Berdasarkan hasil penelitian yang telah dilakukan, dapat diketahui bahwa kontrol diri peserta didik kelas XI SMA N 1 Kedungwuni secara umum memiliki tingkat kontrol diri yang tinggi. Hal tersebut dapat dilihat dari hasil analisis deskriptif yang menunjukkan rata-rata setiap peserta didik mampu mengontrol dirinya secara keseluruhan mencakup kemampuannya mengontrol perilaku, kemampuan mengolah kognitifnya, serta kemampuannya dalam mengambil keputusan. Kontrol diri dapat tercapai apabila individu memiliki ciri-ciri (1) dapat mengontrol perilaku, (2) dapat mengontrol dan menghadapi keadaan, (3) dapat menilai dan menafsirkan keadaan secara subjektif, serta (4) dapat mengambil keputusan.

Setiap individu memiliki kecenderungan untuk melakukan perilaku menyimpang, seperti menyontek, bermain game, tidak mengerjakan tugas, bahkan melakukan pergaulan bebas. Dalam hal ini kontrol diri memiliki peran penting untuk individu berperilaku baik. Menurut Messina dan Messina bahwa kontrol diri memiliki beberapa fungsi, yaitu (1) membatasi perhatian individu pada orang lain, (2) membatasi keinginan untuk mengendalikan orang lain di lingkungannya, (3) membatasi untuk bertingkah laku negatif, (4) membantu memenuhi kebutuhan hidup secara seimbang (Sriyanti 2012). Dari beberapa fungsi tersebut, terlihat 
bahwa peran kontrol diri untuk individu berperilaku baik di lingkungannya sangat besar.

Penelitian ini menilai tingkat kontrol diri peserta didik dari berbagai indikator yang diambil dari aspek-aspek kontrol diri, seperti kontrol perilaku, kontrol kognitif, dan mengontrol keputusan. Dalam hal ini indikator mengontrol keputusan memiliki skor rata-rata paling tinggi dibanding indikator lain. Hal ini menunjukkan bahwa peserta didik kelas XI SMA N 1 Kedungwuni sudah dapat mengontrol dirinya dalam memilih suatu tindakan berdasarkan keyakinan peserta didik. Peserta didik dapat mengambil keputusan atas dirinya.

Indikator lainnya yang masuk dalam kategori tinggi yaitu, kontrol kognitif. Hal ini menunjukkan bahwa peserta didik sudah dapat mengolah informasi yang tidak diinginkan dengan cara menginterpretasi, menilai, atau menghubungkan suatu kejadian dalam suatu kerangka kognitif sebagai adaptasi psikologis atau mengurangi tekanan. Hal ini berarti peserta didik dapat mengontrol kognitifnya secara positif untuk mengolah informasi dari luar.

Indikator paling rendah dibanding indikator lain dalam variabel kontrol diri namun tetap berada dalam kategori sedang, yaitu kontrol perilaku. Hal ini menunjukkan bahwa sebagian peserta didik rata-rata mampu merespon atau memodifikasi keadaan yang tidak menyenangkan.

\section{Tingkat Prokrastinasi Akademik Peserta didik kelas XI SMA N 1 Kedungwuni}

Tingkat prokrastinasi akademik peserta didik kelas XI SMA N 1 Kedungwuni secara umum termasuk dalam kategori cukup $(M=2,62$ dan $S D=0,47)$. Hal tersebut menggambarkan bahwa masih ada peserta didik yang memiliki perilaku prokrastinasi akademik. Selain itu, dari hasil perhitungan didapatkan bahwa indikator dengan rata-rata tertinggi adalah tugas belajar menjelang ujian $(M=3,06$ dan $S D=0,49)$. Hal ini menggambarkan bahwa masih ada peserta didik yang menunda-nunda belajar untuk mempersiapkan ujian. Sedangkan indikator 
dengan rata-rata terendah adalah tugas kehadiran $(M=2,06$ dan $S D=0,51)$. Hal ini menggambarkan bahwa hanya sedikit peserta didik yang melakukan penundaan dalam tugas kehadiran.

Berdasarkan hasil penelitian yang telah dilakukan, dapat diketahui bahwa prokrastinasi akademik peserta didik kelas XI SMA N 1 Kedungwuni secara umum memiliki tingkat prokrastinasi akademik yang cukup. Hal tersebut menunjukkan bahwa masih ada peserta didik yang melakukan penundaan dalam mengerjakan tugas. Individu dikatakan melakukan prokrastinasi akademik apabila memiliki ciriciri yaitu, (1) lebih suka menunda mengerjakan tugas, (2) berpendapat lebih baik mengerjakan nanti dibantingkan sekarang, (3) mengulangi perilaku prokrastinasi secara berkelanjutan, (4) kesulitan dalam mengambil keputusan (Burka dan Yuen, 2008). Penelitian ini menilai tingkat prokrastinasi akademik dari berbagai indikator yang diambil dari area prokrastinasi akademik seperti tugas mengarang, tugas belajar menjelang ujian, tugas membaca mingguan, tugas administratif, tugas kehadiran, dan kinerja akademik secara keseluruhan.

Dalam hal ini indikator tugas belajar menjelang ujian masuk pada kategori cukup yang memiliki rata-rata paling tinggi dibandingkan indikator lain. Hal ini menunjukkan bahwa ada sebagian minat atau persiapan peserta didik kelas XI SMA N 1 Kedungwuni yang tinggi atau cukup untuk mempersiapkan UAS dan ada pula sebagian minat atau persiapan peserta didik kelas XI SMA N 1 Kedungwuni masih rendah dalam belajar untuk mempersiapkan ujian dan lebih memilih melakukan sistem kebut semalam apabila akan diadakan UAS. Baiknya peserta didik tetap belajar untuk mengingat dan memahami kembali pelajaran yang diterima walaupun tidak akan diadakan UAS.

Indikator lain yang masuk dalam kategori cukup yaitu tugas mengarang. Hal ini menunjukkan bahwa masih ada sebagian peserta didik yang menunda melakukan kewajibannya dalam mengerjakan tugas seperti mengerjakan pekerjaan rumah (PR). Baiknya, ketika diberikan pekerjaan rumah (PR) peserta didik langsung mengerjakannya. Hal ini dilakukan untuk mengurangi penumpukan 
PR yang diberikan oleh guru mata pelajaran lainnya, sehingga peserta didik cenderung malas mengerjakan PR.

Indikator lain yang masuk kategori cukup yaitu kinerja akademik secara keseluruhan. Hal ini menunjukkan bahwa masih ada sebagian peserta didik yang menunda dalam mengerjakan tugas akademik secara keseluruhan. Baiknya apabila diberikan tugas peserta didik langsung mengerjakannya untuk menghindari rasa malas yang cenderung terjadi karena adanya penumpukan tugas yang banyak.

Indikator yang masuk kategori cukup berikutnya yaitu tugas membaca mingguan. Hal ini menunjukkan bahwa masih ada sebagian peserta didik yang minatnya rendah dalam membaca ulang materi atau mencari materi tambahan untuk belajar. Baiknya peserta didik membaca ulang pelajaran yang telah diberikan dan membaca materi yang akan diberikan untuk menambah pengetahuan agar lebih memahami materi atau wawasan lainnya yang tidak didapat di mata pelajaran.

Indikator terakhir yang masuk dalam kategori sedang yaitu tugas administratif. Hal ini menunjukkan bahwa rendahnya minat peserta didik untuk mencatat materi yang diberikan dan tidak mencari materi yang tertinggal. Baiknya peserta didik mencatat materi yang diberikan oleh guru untuk mempelajari kembali atau sebagai pengingat ketika belajar secara individu maupun kelompok.

Indikator yang masuk pada kategori rendah yaitu tugas kehadiran. Hal tersebut menunjukkan bahwa masih ada beberapa peserta didik yang menundanunda dalam kehadiran mengikuti pembelajaran, seperti terlambat masuk kelas dan membolos. Baiknya peserta didik belajar tepat waktu dalam memenuhi tugas kehadiran. Hal ini dimaksudkan agar peserta didik lebih disiplin baik dalam belajar secara akademik maupun sosial. 


\section{Pengaruh Kontrol Diri Terhadap Prokrastinasi Akademik Peserta didik kelas XI SMA N 1 Kedungwuni}

Tabel 2. Pengaruh Kontrol Diri terhadap Prokrastinasi Akademik

\begin{tabular}{ccccc}
\hline Model & R & R Square & $\begin{array}{c}\text { Adjusted R } \\
\text { Square }\end{array}$ & $\begin{array}{c}\text { Std. Error of } \\
\text { the Estimate }\end{array}$ \\
\hline 1 & $.764^{a}$ & .584 & .581 & 7.766 \\
\hline
\end{tabular}

Berdasarkan tabel diatas diketahui nilai R Square sebesar 0,584. Dalam nilai tersebut menunjukkan bahwa pengaruh kontrol diri $(\mathrm{X})$ terhadap prokrastinasi akademik (Y) adalah sebesar 58,4\% sedangkan 41,6\% prokrastinasi akademik dipengaruhi oleh variabel lain yang tidak diteliti.

Penelitian ini menunjukkan hasil analisis data bahwa adanya pengaruh yang signifikan antara kontrol diri terhadap prokrastinasi akademik peserta didik. Hal ini diketahui dari hasil analisis regresi sederhana dilihat dari rata-rata. Hal ini dapat diartikan bahwa apabila variabel independent berpengaruh terhadap variabel dependen atau kontrol diri berpengaruh terhadap prokrastinasi akademik.

Berdasarkan hasil penelitian, membuktikan bahwa hipotesis yang diajukan oleh peneliti yaitu menunjukkan "kontrol diri berpengaruh terhadap prokrastinasi akademik pada peserta didik kelas XI SMA N 1 Kedungwuni" di terima. Nilai koefisien pengaruh kontrol diri terhadap prokrastinasi akademik peserta didik menunjukkan nilai yang negatif. Hal tersebut menunjukkan adanya hubungan yang berlawanan arah, yaitu semakin tinggi kontrol diri maka semakin rendah prokrastinasi akademik peserta didik begitupun sebaliknya semakin rendah kontrol diri maka semakin tinggi prokrastinasi akademik peserta didik. Sehingga dapat diartikan bahwa antara kontrol diri dengan prokrastinasi akademik peserta didik saling memiliki pengaruh. 
Selaras dengan hasil penelitian yang dilakukan oleh Indri Muji Sri M bahwa adanya pengaruh kontrol diri terhadap prokrastinasi akademik. Karena seseorang yang memiliki kontrol diri tinggi cenderung dapat mengendalikan dirinya terhadap perilaku-perilaku yang menyimpang seperti prokrastinasi akademik (M Sri 2015). Sama halnya dengan pendapat Santrock (2002:43) bahwa dalam masa perkembangan, remaja meluangkan banyak waktu bersama teman-teman sebaya yang memiliki pengaruh besar di kehidupan remaja, maka dari itu remaja dituntut memiliki kontrol diri untuk membentengi dirinya dari perilaku negatif.

Dilihat dari ketiga indikator kontrol diri, ketiganya sangat memiliki peran penting sebagai faktor yang mempengaruhi kontrol diri. Ketiga indik ator tersebut yaitu kontrol perilaku, kontrol kognitif, dan mengontrol keputusan. Pertama, kontrol perilaku merupakan respon individu secara langsung untuk menghadapi keadaan yang tidak menyenangkan. Manusia adalah makhluk sosial yang setiap waktunya akan berinteraksi langsung dengan manusia lain yang berbeda karakter. Dalam perbedaan karakter umumnya akan memunculnya banyak perbedaan baik sikap, perilaku, pemikiran, dan pendapat. Kontrol perilaku ini memiliki peran penting untuk individu dapat berperilaku baik meskipun terjadi perbedaan dalam berperilaku. Seperti di kelas XI SMA N 1 Kedungwuni, ketika bel masuk berbunyi ada beberapa peserta didik yang memilih masuk kelas agar tidak terlambat mengikuti pelajaran tetapi ada pula beberapa peserta didik yang memilih dudukduduk di kantin dan terlambat mengikuti pelajaran. Hal tersebut menunjukkan bahwa apabila peserta didik memiliki kontrol perilaku yang tinggi maka akan dengan sendirinya mengendalikan keadaan dengan masuk kelas ketika bel berbunyi. Sebaliknya, apabila kontrol perilaku rendah maka peserta didik tidak dapat mengendalikan keadaan dengan tetap duduk-duduk di kantin dan terlambat mengikuti pelajaran.

Kedua, kontrol kognitif merupakan kemampuan individu mengolah informasi yang tidak diinginkan untuk mengurangi tekanan. Perbedaan karakter 
setiap manusia umumnya banyak memunculkan perbedaan pula dalam berpikir. Seperti di kelas XI SMA N 1 Kedungwuni, ketika mendapatkan informasi adanya jam kosong dan diganti dengan pengerjaan tugas secara mand iri. Beberapa peserta didik memilih tidak mengerjakan dan lebih asyik dengan ngobrol dengan temannya atau bermain game. Tetapi ada pula beberapa peserta didik yang memilih untuk mengerjakan tugas yang diberikan agar tugas-tugas yang didapatkan di sekolah tidak menumpuk. Hal ini terlihat bahwa berfungsinya kontrol kognitif peserta didik dalam mengolah informasi dan menilai informasi yang tidak menyenangkan sehingga dapat melakukan pertimbangan untuk memperhatikan segi-segi positif secara subjektif.

Ketiga, mengontrol keputusan merupakan kemampuan individu memilih hasil atau tindakan berdasarkan keyakinan. Perbedaan karakteristik umumnya menimbulkan banyak perbedaan seperti dalam hal berpendapat. Dalam hal ini mengontrol keputusan berfungsi dengan adanya kesempatan, kebebasan, serta tindakan yang akan dipilih individu. Seperti di kelas XI SMA N 1 Kedungwuni, untuk belajar setiap hari tidak semua peserta didik melakukannya. Ada yang tetap belajar untuk mempersiapkan UAS demi mencapai nilai yang diharapkan, ada yang belajar hanya ketika akan UAS dengan melakukan sistem kebut semalam, dan bahkan ada yang tidak belajar walaupun akan UAS. selaras dengan pendapat Mc Farlin dalam Handayani dan Nadiya bahwa pengambilan keputusan merupakan proses mengevaluasi untuk mencapai hasil terbaik yang diharapkan (Handayani 2017). Hal ini menunjukkan bahwa dalam mengontrol keputusan sangat penting untuk peserta didik agar tidak melakukan prokrastinasi akademik.

Berdasarkan hasil penelitian tersebut dapat dikatakan bahwa peserta didik kelas XI SMA N 1 Kedungwuni memiliki kecenderungan melakukan prokrastinasi akademik dengan kategori cukup serta memiliki kontrol diri dengan kategori tinggi. Kontrol diri dan prokrastinasi akademik dalam ranah Bimbingan dan Konseling berkaitan dengan bidang pribadi dan belajar. Kontrol diri berkaitan 
dengan bidang pribadi yang memiliki pemahaman diri secara objektif, baik yang dipengaruhi dari internal maupun eksternal. Prokrastinasi akademik berkaitan dengan bidang belajar dimana perilaku ini merupakan bentuk penyimpangan akademik dalam menunda-nunda dalam penyelesaian tugas akademik. Pentingnya mengembangkan kontrol diri peserta didik dapat dilakukan dengan memmberikan layanan bimbingan dan konseling baik dalam bentuk individu, kelompok, maupun klasikal. Layanan tersebut dapat membantu peserta didik meningkatkan kontrol diri menjadi pribadi yang baik dan dapat menghadapi permasalahan di lingkungan sosial agar tidak melakukan penyimpangan seperti prokrastinasi akademik.

\section{Simpulan}

Berdasarkan hasil penelitian dan pembahasan terkait pengaruh kontrol diri terhadap prokrastinasi akademik peserta didik kelas XI SMA N 1 Kedungwuni, maka dapat disimpulkan bahwa kontrol diri peserta didik kelas XI SMA N 1 Kedungwuni dilihat dari rata-rata sebagian besar menunjukkan kategori tinggi. Hal ini menunjukkan bahwa peserta didik kelas XI SMA N 1 Kedungwuni memiliki kontrol diri yang tinggi, artinya peserta didik memiliki kemampuan untuk mengontrol dirinya baik secara perilaku, kognitif, dan emosi terhadap kejadian yang tidak diinginkan baik sengaja maupun tidak disengaja.

Sedangkan prokrastinasi akademik peserta didik kelas XI SMA N 1 Kedungwuni dilihat dari rata-rata sebagian besar menunjukkan kategori cukup. Hal ini menunjukkan bahwa peserta didik kelas XI SMA N 1 Kedungwuni memiliki prokrastinasi akademik yang cukup, artinya sebagian peserta didik masih melakukan penundaan akademik seperti menyelesaikan tugas, telat masuk kelas, tidak tepat waktu dalam kehadiran, menunda-nunda dalam belajar, serta perilaku prokrastinasi akademik lainnya yang disebabkan karena faktor internal maupun eksternal.

Kemudian terdapat pengaruh negatif dan signifikan kontrol diri terhadap prokrastinasi akademik peserta didik kelas XI SMA N 1 Kedungwuni. Hal tersebut 
menunjukkan bahwa semakin tinggi kontrol diri yang dimiliki peserta didik maka semakin rendah peserta didik melakukan prokrastinasi akademik, begitupun sebaliknya semakin rendah kontrol diri yang dimiliki peserta didik maka semakin tinggi peserta didik melakukan prokrastinasi akademik.

Berdasarkan hasil penelitian tersebut, saran yang diberikan kepada peserta didik yaitu sebaiknya memiliki kontrol diri yang tinggi agar tidak melakukan prokrastinasi akademik. Guru BK di sekolah perlu untuk memantau dan meningkatkan kontrol diri peserta didik yang masih rendah agar tidak terjadi prokrastinasi akademik dalam diri peserta didik. Bagi peneliti selanjutnya, dapat mengembangkan penelitian terkait dengan prokrastinasi akademik dan kontrol diri ini atau dengan mencari variabel lain yang dapat memengaruhi timbulnya prokrastinasi akademik dalam diri individu. 


\section{DAFTAR PUSTAKA}

A., Sutoyo. 2014. Pemahaman Individu (Observasi, Checklist, Interviu, Kuesioner, Sosiometri). Yogyakarta: Pustaka Pelajar.

Arikunto, Suharsimi. 2007. Manajemen Penelitian. Jakarta: Rineka Cipta.

Bastomi, H. (2017). Menuju Bimbingan Konseling Islami. KONSELING EDUKASI: Journal of Guidance And Counseling, 1 No. 1. https://doi.org/10.21043/konseling.v1i1.4434

Bastomi, H. (2019). Konseling Cyber: Sebuah Model Konseling Pada Konteks Masyarakat Berbasis Online. Konseling Edukasi: Journal of Guidance and Counselling, 3, No. 1.

Bastomi, H. (2020). Pemetaan Masalah Belajar Siswa SMK Negeri 3 Yogyakarta Dan Penyelesaiannya (Tinjauan Srata Kelas). KONSELING EDUKASI: Journal of Guidance And Counseling, 4 No. 1.

Burka, J.B \& Yuen, L.M. 2008. Procrastination. Cambridge: Da Capo Press.

Ghufron, N. M. \& Risnawati, R. 2016. Teori-Teori Psikologis. Jogjakarta: Arruzz Media.

Ghufron, N.M. \& Risnawati, R. 2010. Teori-Teori Psikologi. Jogjakarta: Arruz Media.

Ghufron, M.N. 2003. "Hubungan Kontrol Diri Dan Persepsi Remaja Terhadap Penerapan Disiplin Orang Tua Dengan Prokrastinasi Akademik." Universitas Gadjah Mada Yogyakarta.

Handayani, Sri W R I \& Nadiya Andromeda. 2017. "Pengaruh Gaya Pengambilan Keputusan Terhadap Prokrastinasi Akademik Pada Mahasiswa." Psikovidya 21(1): 64.

Hurlock, E.B. 1994. Psikologi Perkembangan: Suatu Pendekatan Sepanjang Rentang Kehidupan. Jakarta: Erlangga.

M Sri, Indri Muji. 2015. "Hubungan Kontrol Diri Dengan Perilaku Prokrastinasi Akademik Pada Siswa Kelas VII MTS Tarbiyatul Islamiyah Jakenan Semester Genap Tahun Pelajaran 2014/2015." Universitas Nusantara PGRI Kediri.

Mertha Jaya, I Made L. 2020. Metode Penelitian Kuantitatif Dan Kualitatif: Teori, Penerapan, Dan Riset Nyata. Yogyakarta: Penerbit Quadrant.

Muhid, A. 2009. "No TitleHubungan Antara Self-Control Dan Self-Efficacy Dengan Kecenderungan Perilaku Prokrastinasi Akademik Mahasiswa Fakultas 
Dakwah." Jurnal Ilmu Dakwah 18. http://www.librarygunadarma.com.

Nova. 2012. "Remaja, Globalisasi, Dan Gaya Hidup." http://psg.uii.ac.id/index.php/RADIO/4Februari.html.

Santrock, John W. 2003. Adolescence, Perkembangan Remaja. Keenam. Jakarta: Erlangga.

Solomon, Laura J and Eather D. Rothblum. 1984. "Academic Procrastination: Frequency and Cognitive-Behavioral Correlates." Journal of Counseling Psychology 33(4): 503-9.

Sriyanti, Lilik. 2012. "Pembentukan Self Control Dalam Perspektif Nilai Multikultural." Jurnal Sekolah Tinggi Agama Islam Negeri Salatiga 4(1): 71.

Sugiyono. 2016. Metode Penelitian Pendidikan Pendekatan Kuantitatif, Kualitatif, Dan R\&D. Bandung: ALFABETA. 